\title{
Pemaafan pada Perempuan Korban Perselingkuhan dalam Hubungan Perkawinan
}

\author{
Forgiveness for Women Victims of Infidelity in \\ Marital Relations
}

\author{
Rischa Deviana ${ }^{1}$, Istar Yuliadi $^{2}$, Laelatus Syifa Sari Agustina ${ }^{3}$ \\ 1,2,3 Program Studi Psikologi, Fakultas Kedokteran Universitas Sebelas Maret \\ Surakarta Jl. Ir. Sutami No.36, Kentingan, Kec. Jebres, Kota Surakarta, Jawa Tengah \\ 57126 \\ rischadeviana@gmail.com
}

\begin{abstract}
Infidelity can occur in various circles, forgiveness is not about letting other people get out of trouble, but about how to let ourselves get out of the problem. Through forgiveness, the hearts of women who are victims of infidelity no longer suffer the psychological consequences of the injustices they have experienced. Forgiveness, when properly accepted, can be a healthy response to infidelity. The purpose of this study is to describe how the process of forgiveness in women as a response to victims of infidelity. This study uses a qualitative method. In collecting data, researchers used data triangulation methods, namely curriculum vitae, observations, and interviews. The results of research conducted on several respondents showed that the subject interpreted infidelity differently, including seduced partners, opportunities, and the influence of the friendship environment, the emergence of unexpected aggressive behavior from individuals. Several factors influence the subject in maintaining his marriage, including there are supporting factors, namely the child factor, family support, religion, and still have a sense of affection for the partner. While the inhibiting factors are the prolonged quarrel between the perpetrator and the victim as well as economic problems.
\end{abstract}

Keywords: forgiveness, female victims of infidelity, infidelity,

\begin{abstract}
ABSTRAK. Perselingkuhan dapat terjadi di berbagai kalangan,pemaafan bukan tentang membiarkan orang lain lepas dari masalah, namun tentang bagaimana membiarkan diri kita lepas dari permasalah tersebut. Melalui pemaafan, hati perempuan korban perselingkuhan tidak lagi menanggung derita psikologis akibat dari ketidakadilan yang dialaminya. Pemaafan, jika sudah diterima dengan benar, bisa menjadi respons yang sehat terhadap perselingkuhan. Tujuan dari penelitian ini adalah untuk mendeskipsikan bagaimana proses pemaafan pada perempuan sebagai respon dari koban perselingkuhan. Penelitian ini menggunakan metode kualitatif. Dalam mengumpulkan data peneliti menggunakan metode triangulasi data, yaitu riwayat hidup, observasi, dan wawancara. Hasil penelitian yang dilakukan kepada beberapa responden menunjukkan subjek memaknai perselingkuhan dengan berbeda, diantaranya pasangan tergoda, adanya kesempatan, dan pengaruh lingkungan pertemanan, munculnya perilaku agresi yang tidak terduga dari individu. Beberapa faktor mempengaruhi subjek dalam mempertahankan perkawinannya, diantaranya terdapat faktor yang mendukung yaitu faktor anak, dukungan keluarga, agama, dan masih memiliki rasa sayang kepada pasangan. Sedangkan faktor yang menghambat adalah pertengkaran yang berkepanjangan antara pelaku dan korban serta masalah ekonomi.
\end{abstract}


Kata kunci: Pemaafan, Perempuan korban perselingkuhan, Selingkuh

\section{Pendahuluan}

Setiap pasangan pasti menginginkan bahtera rumah tangga yang langgeng, awet, dan bahagia (Wijayanti, 2015). Banyak pasangan yang berharap dapat menghabiskan waktu bersama pasangannya hingga akhir hayat. Namun, faktanya di balik kebahagiaan yang tampak nyaman justru dalam perkawinan itu sendiri selalu timbul permasalahan yang berdampak dan menjadi pemicu sumber stress. Rasa tidak puas terhadap pasangan sering memicu keinginan untuk memenuhi kebutuhan lahir dan batin dengan menjalin hubungan dengan pihak yang bukan pasangannya. Hal inilah yang menyebabkan terjadinya perceraian yang disebabkan ketidaksetiaan pasangan dan sebagian besar didominasi oleh ketidaksetiaan para suami (Hapsari, 2014). Hidayat dalam hokum online (2018) mengatakan bahwa putusan perceraian pada Pengadilan Agama di Indonesia mengalami peningkatan dalam kurun waktu tiga tahun terakhir (2015-2017). Tercatat dalam catatan tahunan Komnas Perlindungan Wanita data perceraian di Indonesia pada tahun 2012 sampai 2016 sebanyak 1.298.585 dan setidaknya terdapat 187.558 (14,46\%) perceraian yang disebabkan perselingkuhan (dalam Komnas Perlindungan Wanita, 2017). Data Pengadilan Agama Pati (2018) menyatakan setiap bulan terjadi pengaduan kasus perceraian sebanyak 200 sampai

350 kasus. Pada tahun 2018 di kabupaten Pati tercatat 3462 kasus gugatan dan yang diputus cerai sebanyak 3252 kasus. Pada tahun 2019 terdapat 2.691 kasus perceraian yang telah diketuk palu maupun dalam proses. Panitera Muda Hukum PA Pati Sabil Huda dalam murianews (2019) menyatakan bahwa ada banyak faktor gugatan cerain yang diajukan baik dari pihak istri maupun suami, namun yang paling dominan adalah faktor perselingkuhan.

Menurut Sing, pal dan Kuwar (dalam Zalafi, 2015) perselingkuhan merupakan hubungan seseorang yang sudah menikah dengan seseorang yang bukan pasangan sahnya. Menurut Jacson (2000) Perselingkuhan adalah hubungan antara pria dengan wanita tanpa sepengetahuan pasangan yang sah dengan melibatkan hubungan fisik maupun emosional antara keduanya, yang mana didalamnya termasuk saling ketertarikan, ketergantungan dan saling memenuhi. Bird dan Melville (dalam Fretes dkk, 2016) menyataka bahwa perilaku perselingkuhan merupakan tindakan membagi keintiman emosional atau seksual dengan seseorang di luar hubungan utama tanpa persetujuan dari pasangan lainnya. Rizmainun (2017) menyebutkan salah satu alasan individu berselingkuh 
adalah faktor keuangan dimana individu memilki uang yang berlebih kemudian tidak disertai dengan moralitas yang baik maka akan dengan mudah tergoda dengan pihak ketiga. Edward (2018) mengatakan bahwa satu cara melihat apakah seseorang berpotensi tidak setia adalah dari penghasilannya dimana individu yang berpenghasilan lebih tinggi dari pasangannya cenderung akan selingkuh, terutama individu yang merasa kurang dihargai. Harian Republika (2014) menyatakan perselingkuhan mengalami perubahan bentuk dari yang tidak lazim menjadi suatu hal yang biasa. Hal itu menyebabkan perselingkuhan secara kualitatif dan kuantitatif mengalami peningkat. Perselingkuhan dapat terjadi di berbagai kalangan, seperti kasus yang terdapat pada patinews (2014) yaitu perselingkuhan antara oknum PNS kasi kesiapsiagaan BPBD Pati dengan salah satu peserta relawan wanita pada saat pelatihan SAR yang diadakan bulan oktober 2013 di waduk seloromo gembong. Berdasarkan dari situs suarapatinews (2017), salah satu oknum PNS dari Kementrian Hukum dan Ham melakukan perselingkuhan hingga menyebabkan selingkuhanya hamil namun, pada akhirnya benih yang dikandung digugurkan atas bujukan oknum PNS tersebut. Murianews (2018) menguak perselingkuhan antara kades wedusan dengan warganya sendiri. Aksi perselingkuhan yang dilakukan okum PNS merupakan hal yang wajar. Berdasarkan situs Relationships Australia (2018), pada Januari 2018

Relationships Australia melakukan sebuah survey online bulanan yang meminta pengunjung situs web tersebut untuk melaporkan pemahaman mereka mengenai perselingkuhan. Sekitar 1800 orang merespon survey online tersebut pada Januari 2018. Ketika ditanya mengenai jenis perselingkuhan yang paling berbahaya, sebagian besar responden survei melaporkan bahwa semua jenis perselingkuhan sama-sama berbahaya (pria 41\% dan wanita 58\%).

Penelitian yang dilakukan oleh Buss (2018) menghasilkan bahwa pria lebih memandang perselingkuhan dari aspek seksual dari pada emosional, sedangkan wanita memandang perselingkuhan dari aspek emosional dari pada seksual. Adamopoulou (2013) melakukan penelitian di Amerika dengan menggunakan 90.000 sampel menemukan jika presentasi pria yang melakukan perselingkuhan sebanyak 56,8\% dan wanita sebanyak 55,8\%. Novianty (2017) dalam suara.com menyebutkan survey yang dilakukan Justdating menemukan bahwa 40\% laki-laki dan perempuan di Indonesia pernah selingkuh sehingga memposisikan Indonesia sebagai negara dengan kasus perselingkuhan terbanyak nomer dua di Asia Tenggara.

Ada berbagai macam solusi yang dapat ditempuh bagi pasangan suami istri demi mempertahankan rumah tangga, salah satunya dengan melakukan pemaafan 
(Cempaka, 2015). Pemaafan mampu mengurangi kebiasaan pendendam dan akan berdampak berkurangnya emosi negatif seperti kebencian, dendam dan keinginan untuk balas dendam (Safarina, 2014). Pemaafan juga dapat didefinisikankeinginan untuk meninggalkan hak untuk membenci, memberi pandangan negatif dan diskrimansi terhadap seseorang yang telah menyakitinya dan bahkan mengembangkan sikap sabar, ramah dan bahkan kasih sayang terhadap pihak yang telah menyakitinya (Meryem, 2017). Baumeister dan Exline (2000) menjelaskan bahwa pemaafan terjadi dikarenakan adanya kesalahan yang diperbuat oleh pelaku dan adanya keingian dari korban untuk melepaskan pelaku dari rasa bersalah atas kesalahannya. Korban menunjukan respon yang berbedabeda ketika mereka mengetahui pasangannya selingkuh untuk pertama kali, namun pada akhirnya korban memilih untuk kembali kepasangannya. Sejatinya, pemaafan bukan tentang membiarkan orang lain lepas dari masalah, namun tentang bagaimana membiarkan diri kita lepas dari permasalah tersebut. Melalui pemaafan, hati perempuan korban perselingkuhan tidak lagi menanggung derita psikologis akibat dari ketidakadilan yang dialaminya. Pemaafan, jika sudah diterima dengan benar, bisa menjadi respons yang sehat terhadap perselingkuhan. Dalam penelitian ini peneliti ingin mengetahui secara lebih mendalam mengenai "Dimensi Pemaafan pada Perempuan Korban Perselingkuhan dalam Hubungan Perkawinan”.

\section{Metode}

Penelitian ini menggunakan metode kualitatif dengan pendekatan fenomenologi. Kahija (2017) menjelaskan bahwa IPA berfokus pada pikiran, perasaan, sikap, atau kepercayaan dari sudut pandang orang yang mengalami kejadian secara langsung. IPA merupakan analisis yang menjalankan 3 pilar penelitian yaitu (1) fenomenologi yang bersandar pada epochē, (2) interpretasi yang bersandar pada pemahaman setiap pernyataan partisipan tanpa melepaskannya dari seluruh transkrip, dan (3) idiografi yang memperhatikan keunikan partisipan (Kahija, 2017). Langkah-langkah dalam analisis data adalah sebagai berikut membaca berkali-kali, membuat catatan-catanan awal, perumusan tema emergen, perumusan tema superordinat, analisis pola-pola antar kasus, penataan seluruh tema superordinat, serta melaporkan hasil analisis dan pembahasan. Dalam mengumpulkan data peneliti menggunakan metode triangulasi data, yaitu riwayat hidup, observasi, dan wawancara. Karakteristik subjek dalam penelitian merupakan seorang istri yang mengalami perselingkuhan 
secara emosional dan seksual, memilih mempertahankan pernikahan, dan memiliki anak.

\section{Hasil Penelitian}

Penelitian ini melakukan wawancara terhadap dua orang wanita korban perselingkuhan seperti kriteria yang telah ditetapkan. Adapun gambaran subyek penelitian dapat dijelaskan sebagai berikut:

\begin{tabular}{|lllll|}
\hline No & Nama & Usia Pernikahan & Pekerjaan & Pendidikan \\
1 & IF & 17 & Pedagang & SMA \\
2 & AMW & 24 & PNS & S1 \\
\hline
\end{tabular}

Kedua subjek menunjukan respon yang sama ketika pertamakali mengetahui perselingkuhan pasangannya berupa emosi, kognisi, dan perilaku negative terhadap pasangan. Subjek 1 (IF) maupun subjek 2 (AMW), keduanya mengalami intrapsikis dan interpersonal negatif terhadap pasangannya. Intrapsikis yang dialami oleh kedua subjek dalam bentuk emosi negatif berupa perasaan marah, kecewa, sakit hati, maupun benci terhadap pasangan. IF merasa sangat kecewa, sakit hati, dan sementara AMW Kedua subjek menilai pasangannya salah, tidak bertanggung jawab dan sering menghindar ketika dimintai penjelasan. Sementara itu, interpersonal dalam bentuk perilaku negatif yang dilakukan terhadap pasangan dapat berupa menyalahkan, membentak, memarahi, hingga memukulpasangannya. Kedua subjek berada pada fase ketidakmaafan saat pertama kali mengetahui perselingkuhan pasangan yang menyebabkan tidak terjadinya intrapsikis dan interpersonal pada diri subjek.

Respon yang ditunjukan kedua subjek selama terjadinya perselingkuhan berupa emosi, kognisi, dan interpersonal negative terhadap pasangan. Emosi negatif yang dilami subjek berupa berupa kecewa, sakit, hati, marah, bahkan benci terhadap pasangan. Baik IF maupun AMW, keduanya sama-sama merasa marah, kecewa, dan sakit hati terhadap pasangan. Selain merasakan emosi negatif keduanya juga mengalami kognisi negatif berupa pasangan yang dinilai tidak bertanggung jawab. Keduanya menilai pasangannya tidak bertanggug jawab atas subjek dan anak-anaknya. Di samping emosi dan kognisi negatif, IF dan AMW juga melakukan perilaku negatif. Perilaku negatif yang dilakukan keduanya berupa agresi baik secara verbal maupun nonverbal. Agresi ini dilakukan kedua subjek setelah mengetahui pasangannya melakukan perselingkuhan. Keduanya juga menunjukan perilaku tidak menerima perselingkuhan yang dilakukan oleh pasangannya. Kedua 
subjek sama-sama mendatangi selingkuhan pasangan sebagai bentuk kekecewaan dan sakit hati. Sementara itu, AMW menempatkan mata- mata serta mencari tahu sebagai bentuk ketidakpercayaan subjek terhadap pasangan.

Subjek 1 (IF) telah memutuskan untuk memaafkan pasangan setelah pasangannya memperlakukan subjek serta anak-anaknya dengan baik sebagai wujud rasa bersalah dari pasangannya serta keinginan subjek untuk mempertahankan perkawinan. Selain itu, IF menganggap memaafkan pasangannya merupakan suatu hal yang penting karena memaafkan pasangannya untuk mempertahankan perkawinannya serta agar hubungan dengan pasangan harmonis sehingga anak subjek tidak perlu menderita karena menjadi korban perceraian kedua orang tuanya. Subjek mulai memandang positif pasangannya yang telah menunjukan perilaku yang baik kepada subjek serta memandang pasangannya kembali perhatian dengan anakanaknya. Sementara itu, AMW memutuskan belum memafkan pasangannya. Hal ini dikarenakan, tidak terjadinya intrapsikis dan interpersonal pada subjek sehingga subjek masih merasakan emosi-emosi negatif dan dendam sama seperti saat AMW pertamakali mengetahui perselingkuhan yang dilakukan oleh pasangannya. Subjek belum memberikan pemaafan karena belum yakin jika pasangan bisa berubah serta tidak mengulangi kesalahannya. AMW menilai pasangannya sebagai sosok suami dan ayah yang tidak wajar. Hal ini dikarenakan pasangan AMW sudah tidak perduli lagi dengan subjek bahkan dengan ketiga anaknya

\section{Pembahasan}

Subjek pertama menganggap bahwa perselingkuhan yang dilakukan pasangannya karena adanya kesempatan, sedangkan subjek kedua mengaku perselingkuhan yang dilakukan pasangannya dikarenakan lingkungan pertemanan dan kenaikan jabatan. Berdasarkan latar belakang kedua subjek tersebut dapat dikatakan bahwa faktor yang menyebabkan terjadinya perselingkuhan berbeda. Pada AMW, pengkhianatan yang dilakukan pasangan disebabkan oleh faktor pasangannya naik jabatan serta pegaruh lingkungan pertemanan pasangannya. Kemudian pasangan AMW berubah menjadi pribadi yang tertutup, tidak jujur dengan penghasilan yang diperoleh serta menjalin hubungan dengan perempuan lain yang berimbas pada suami subjek memberikan seluruh gajinya untuk menghidupi kebutuhan perempuan tersebut. Perilaku pasangannya inilah yang menjadi salah satu faktor pemicu terjadinya pertengkaran dan konflik antara AMW dan pasangan yang tidak dapat diselesaikan dengan baik terlebih lagi pasangan subjek sering menghindar dan selalu menyangkal ketika menyelesaikan 
masalah. Konflik antara subjek dengan pasangan semakin memburuk lantaran pasangan melakukan kekerasan baik secara fisik maupun psikis.

Kedua subjek mengalami dampak perselingkuhan baik secara psikologis, sosial, maupun fisik. Selama perselingkuhan kedua subjek merasakan emosi negative terhadap pasangannya. Baik IF maupun AMW, keduanya sama-sama merasakan dampak emosi negative berupa perasaan sakit hati, kesal, terkejut, kecewa, cemas, takut, sedih, dan marah. Perselingkuhan yang dilakukan suami juga dapat memberikan luka psikologis, seperti kehilangan kepercayaan diri, shock, menyalahkan diri sendiri, marah, kehilangan kendali diri, hingga kehilangan kepercayaan terhadap suami (Zalafi, 2015). Kedua subjek di dalam lingkungan sosialnya sering menjadi bahan pergunjingan, mendapat cemoohan, bahkan dikucilkan. Subjek pertama mengalami dampak secara fisik berupa penurunan nafsu makan yang berimbas pada berat badan subjek turun secara drastis. Hasil penelitian Shrout (2017) ini menunjukkan bahwa menjadi korban perselingkuhan dapat meningkatkan stress secara psikis seperti kecemasan berlebih dan depresi, serta perilaku berisiko seperti konsumsi alkohol berlebihan, hingga gangguan makan atau olahraga yang tidak normal. Subjek pertama juga merasakan kepala hingga ubun-ubun subjek terasa "gembuk" dan sakit kepala.

Faktor permintaan maaf dari pasangan juga mendorong IF mengambil keputusan untuk memaafkan pasangannya. Sejalan dengan teori yang dikemukakan McCullough (2000) bahwa permintaan maaf dari pelaku yang menyakiti akan semakin memotivasi korban untuk memberikan pemaafan. Hal ini dikarenakan, permintaan maaf dari pelaku akan membuat korban memunculkan empati. Munculnya empati dari korban kepada pelaku tentu mendukung korban untuk memberikan pemaafan kepada pelaku dan apa yang telah diperbuatnya (Enright \& North, 1998; McCullough, Rachal, Sandage, Worthington, Brown \& Hight, 1998; McCullough, 2000).

Faktor agama berperan penting dalam munculnya pemaafan (Wothington dan Wade, 1999) dimana agama yang dianut oleh IF mengajarkan akan kesabaran dalam menghadapi ujian yang membuatnya bisa memperoleh pahala sabar dan memberi keyakinan bahwa semua ujian membawa hikmahnya. Menurut Wothington dan Wade (1999) pemeluk agama yang berkomitmen dengan ajaran agamanya akan memiliki nilai tinggi pada pemaafan dan nilai rendah pada ketidakmaafan (unforgiveness). Hal ini sejalan dengan yang dialami IF dimana subjek berusaha menaati perintah agama untuk sabar dan memaafkan sesakit apapun yang dirasakan. Subjek percaya kesabarannya akan mengembalikan pasangannya. 
AMW juga menganggap dengan memberikan pemaafan pada pasangannya dapat merugikan dirinya serta mengancam harga dirinya. Selain itu, AMW tidak yakin dengan pemaafan pasangannya akan berubah kearah yang positif serta tidak mengulangi kesalahannya. AMW juga mendapatkan dampak sosial sementara pasangannya tidak. Kedua faktor tersebut sesuai dengan faktor harga diri dan dendam serta faktor menyalahi prinsip yang diungkapkan Baumeister, Exline, dan Sommer (dalam Worthington, 1998).

Baumeister, Exline, dan Sommer (dalam Worthington,1998) mengungkapkan bahwa faktor harga diri dan dendam menjadikan individu enggan untuk memaafkan pihak yang bersalah karenaakan merusak harga dirinya dan menjadikannya terlihat bodoh.

Berdasarkan berbagai perbedaan latar belakang pernikahan yang dialami, masing-masing subjek memiliki alasan tersendiri mengapa mereka memilih untuk bertahan. Kedua subjek memilih untuk mempertahankan pernikahannya dengan pasangan, meskipun mereka mengalami hal yang menyakitkan. Baik IF maupun AMW memilih untuk mempertahankan perkawinannya demi anak-anaknya. Meskipun kedua subjek merasakan berbagai emosi negatif, namun kedua subjek memilih mengesampingkan hal tersebut dikarenakan subjek lebih mempertimbangkan dampak buruk yang akan diterima anak-anaknya apabila subjek memutuskan untuk bercerai. Selain itu, kedua subjek tidak ingin anaknya kehilangan sosok seorang ayah. Pertimbangan lain seperti rasa sayang yang masih dirasakan, harapan bahwa kondisi rumah tangga ke depan dapat menjadi lebih baik, perilaku pasangannya berubah menjadi baik, serta pasangan yang beritikad baik ingin mempertahankan pernikahan, membuat IF yakin untuk mempertahankan rumah tangganya. IF berusaha untuk memaafkan dan mengatasi emosi-emosi negatif yang dirasakannya akibat perselingkuhan pasangannya. IF menyadari bahwa sebenarnya suaminya adalah orang yang baik dan suatu hari nanti akan sadar dan kembali ke keluarga. Disisi lain, AMW memilih mempertahankan pernikahannya karena anak serta teringat akan sumpah yang diucapkan bahwa menikah sekali untuk seumur hidup.

\section{Kesimpulan}

Berdasarkan hasil penelitian, diperoleh beberapa kesimpulan yaitu (1) Kedua subjek memaknai perselingkuhan dengan berbeda, diantaranya pasangan tergoda, adanya kesempatan, dan pengaruh lingkungan pertemanan. (2) Kesamaan antar subyek yaitu kedua subyek sama - sama memiliki waktu perkenalan yang singkat menuju pernikahan dan memilih mempertahankan pernikahan. 
Berdasarkan proses pemaafan terhadap pasangan, terlihat bahwa keduanya memiliki hasil yang berebeda. Perbedaan antar subyek yaitu subyek pertama telah memaafkan sepenuhnya yaitu dengan menerima masa lalu atas perbuatan yang dilakukan oleh pasangannya sebagai upaya untuk mempertahankan rumah tangga serta untuk melepaskan emosi-emosi negative yang ada pada subjek. Subjek kedua tidak memafkan perbuatan dari pasangannya dikarenakan subjek kedua masih belum yakin pasangannya berubah menjadi lebih baik serta tidak mengulangi perbuatannya.

\section{Implikasi}

Berdasarkan penelitian ini dapat diberikan beberapa saran sebagai berikut, dukungan keluarga dan orang terdekat memiliki peranan yang sangat penting bagi subjek sehingga subjek tidak berlarut-larut tenggelam dalam emosi negatif yang dirasakannya dan mampu memaafkan dirinya maupun pasangannya dan dapat menyadari bahwa pemaafan dapat sebagai upaya untuk mengembalikan keutuhan rumah tangga akibat perselingkuhan pasangan. Masyarakat diharapkan dapat memberikan dukungan psikologis yang bertujuan untuk pemulihkan kondisi psikologis subjek pasca menjadi korban perselingkuhan. diharapkan dapat dikembangkan lebih lanjut mengenai pemaafan berkaitan dengan pemilihan subjek yang lebih luas dan beragam, misalnya melihat upaya dari pemaafan pada suami yang diselingkuhi oleh istrinya.

\section{Daftar Pustaka}

Adamopoulou, E. (2013). New facts on infidelity. Economics Letters, 121 (2013), 458-462.

Anna, L. K. (2017). Penghasilan Tinggi, Godaan Selingkuh Juga Besar. Kompas.com. Retrieved November 8, 2019, from https://lifestyle.kompas.com/read/2017/04/06/081200720/penghasilan.ting gi.godaan.selingkuh.juga.besar

Anwar, C. (2019, Agustus). Tiap bulan 300-an perempuan di pati beralih status jadi janda. Murianew.com. Retrived Agustus 11, 2019, https://www.murianews.com/2019/11/13/176595/tiap-bulan-300-anperempuan-di-pati-beralih-status-jadi-janda.html.

Baumeister, R., \& Exline, J. (2000). Self-control, morality, and human strength. Journal of Social and Clinical Psychology, 19, 29-42

Bird, E., \& Melville, K. (1994). Families and Intimate Relationship. New York: Mc.Graw Hill, Inc. 
Buss, D. M. (2000). The dangerous passion: why jealousy is as necessary as love and sex. New York: Free Press.

Cempaka, A. L. (2015). Faktor-faktor yang mempengaruhi forgiveness dalam pernikahan di kecamatan Makasar, Jakarta Timur (Skripsi). Jakarta: Fakultas Psikologi Universitas Islam Negeri Syarif Hidayatullah.

Fretes, M. D., Nancy, M. N., \& Anggraini, S. (2016). Wife's forgiveness for husband's affair's (qualitative study of woman as victims of husband's affairs in maumere). Psycologi Forum, 592 - 599.

Hapsari, E. (2014, Januari). Mengapa Terjadi Banyak Perselingkuhan?. republika.co.id. Retrieved November 8, 2019, from Republika.http://www.republika.co.id/berita/humaira/samara/14/01/22/ m zrv4d-mengapa-banyak-terjadi-perselingkuhan.

Jackson, M. (2000). When a spouse is unfaitfull. USA : RBC MinistriesGrand Rapids.

Komnas Perempuan. 2017. Ringkasan Eksekutif. Catatan Tahunan Komnas Perlindungan Wanita 2017: Author.

La Kahija, Y. F. (2017). Penelitian Fenomenologis Jalan Memahami Pengalaman Hidup. Jogjakarta: Kanisius.

Novianty, D. (2017, Desember) . Survei: Indonesia negara kedua di asia paling banyak selingkuh. Suara.com. Retrieved November 8, 2019, from https://www.suara.com/lifestyle/2017/12/02/142256/survei-indonesianegara-kedua-di-asia-paling-banyak-selingkuh.

Patinews. (2014, Mei). Oknum PNS BPBD Pati Diduga Selingkuh Dengan Relawan Wanita Saat Pelatihan SAR. patinews.com. Retrieved Agustus 12, 2019, from https://www.patinews.com/oknum-pns-bpbd-pati- didugaselingkuh-dengan-relawan-wanita-saat-pelatihan-sar/

Relationships Australia. (2018, Januari). January 2018: Infidelity. Relationships.org.au. Retrived Agustus 11, 2019, from https://www.relationships.org.au/what-we-do/research/onlinesurvey/january-2018-infidelity.

Pengadilan Agama Pati. (2018). Statistik perkara. Pa-Pati.go.id. Retrieved Agustus 12, 2019, from http://pa-pati.go.id/sipp/statistik_perkara.

Republika. (2014, September). Mengapa pasangan bisa berselingkuh?. Republika.co.id. Retrived Agustus 11, 2019, from https://republika.co.id/berita/humaira/samara/mt02o2/mengapa- pasanganbisa-berselingkuh.

Rizmainun. (2017). Suami selingkuh?Ini Penyebab-penyebabnya. Ruangmuslimah.com. Retrived Agustus 11, 2019, from www.ruangmuslimah.com/amp/21585-suamiselingkuh-ini penyebabnya?espv=1.

Safarina, T. (2014). Forgiveness, Gratitude, and happiness among College Students. International Jurnal of public health Science, 3, 241 -245. 
Shrout, M. R., \& Weigel, D. J. (2017). Infidelity's aftermath: Appraisals, mental health, and health-compromising behaviors following a partner's infidelity. Journal of Social and Personal Relationships, 35(8), 1067-1091.

Suarapatinews. (2017, Agustus). Di duga pegawai lapas pati merebut istri tetangganya sendiri. suarapatinews.com. Retrieved Agustus 12, 2019, from https://suarapatinews.com/2017/08/di-duga-pegawai-lapas-patimerebut-istri-tetangganya-sendiri/

Wijayanti. (2015, Februari). "5 Kebiasaan romantis agar pernikahan selalu harmonis". nova.grid.id. Retrieved Agustus 12, 2019, http://nova.grid.id/Keluarga/Pasan gan/5-Kebiasaan-RomantisAgarPernikahan-Selalu-Harmonis.

Worthington, E. L., \& Wade, N. G. (1999). The Psychology of Unforgiveness and Forgiveness and Implications for Clinical Practice. Journal of Social and Clinical Psychology, 18.

Worthington, E. L., Jr., Kurusu, T. A., Collins, W., Berry, J. W., Ripley, J. S., \& Baier, S. N. (2000). Forgiving usually takes time: A lesson learned by studying interventions to promote forgiveness. Journal of Psychology and Theology, $28,3-20$.

Worthington, E. L., Witvliet, C., Pietrini, P., \& Miller, A. J. (2007). Forgiveness, health, and well-being: A review of evidence for emotional versus decisional forgiveness, dispositional forgivingness, and reduced unforgiveness. Journal of Behavioral Medicine, 30, 291-30

Zalafi, Z. (2015). Dinamika Psikologis Perempuan yang Mengalami Perselingkuhan Suami (Skripsi). Yogyakarta : Universitas Islam Negeri Sunan Kalijaga. 